\section{A BIZTOSÍTÁSI SZERZŐDÉSSEL ÖSSZEFÜGGŐ, TÁJÉKOZTATÁSI SZABÁLYOKKAL KAPCSOLATOS KÁRFELELÖSSÉG, KÜLÖNÖS TEKINTETTEL A KÖZVETÍTŐI HELYZETEKRE}

Újváriné Dr. Antal Edit ( címzetes egyetemi docens, ügyvéd, ME ÁJK Civilisztikai Tudományok Intézete, Kereskedelmi Jogi Tanszék)

\section{ÖSSZEFOGLALÓ}

Az egységes európai biztosítási piac résztvevői a követelmények szigorodásával néznek szembe, de az ügyfél, a fogyasztó sem tud könnyen eligazodni az őt védő, jogszabályok által sokszor „halmozott” tájékoztatási kötelezettség körében, amely megjelenik mind a prekontraktuális szakaszban, mind pedig a jogviszony fennállása alatt. Az ügyfél felé fennálló tájékoztatási kötelezettséggel kapcsolatos, biztosítókra, biztositásközvetítőkre vonatkozó közjogi szabályok megsértése közjogi szankciót von maga után, de a magánjogi jogviszonyban is következménnyel járhat. Tanulmányunkban arra kívánunk rámutatni, hogyan kapcsolódnak össze a közjogi és a magánjogi szabályok a deliktuális és a kontraktuális kárfelelősségben, megvilágítva a különböző lehetséges igények egymáshoz való viszonyát.

\section{SUMMARY}

The participants of the single European insurance market face massive burden with the severity of requirements, however not even the consumer is able to navigate among the information requirements cumulated often by law protecting consumer in precontractual and contractual phase. Public law contains provisions in connection to information requirements of insurance companies and insurance intermediaries toward customers as well as sanction of breach of this provisions; but also private law has importance in this context. In our study we refer to the connection of public and private norms in delictual and contractual liability reflecting recent legislation, the relationship between the different enforceable claims is also being examined.

Kulcsszavak: prekontraktuális, tájékoztatási kötelezettség, szerződésszegési kárfelelősség, szerződésen kívüli kárfelelősség, távértékesítés

Key words: pre-contractual, information duty, contractual liability, non-contractual liability, distance selling

JEL: G22, K12, K15

DOI: $10.18530 / \mathrm{BK} .2018 .2 .48$

http://dx.doi.org/1018530/BK.2018.2.48

\section{Rövid áttekintés az európai jogegységesítési folyamatról}

Az egységes biztosítási piacot szabályozó irányelvek alapvető célja a biztosítási termék szabad áramlásának a megteremtése, így rendelkezéseik kihatnak a biztosítási szerződési jogra. Ugyanakkor a biztosítási szerződési jog is közvetlen hatással van az európai biztosítási piacra, hiszen az eltérő tagállami szabályok akadályát jelentik a piac kibontakozásának. Az irányelvek három „nemzedéke” és azok módosításai, illetve az azokat felváltó irányelv nem célzottan, áttételes hatással ugyan, ám nagy jelentőségűek a biztosítási szerződési jog fejlődése tekintetében is, ${ }^{1}$ de a biztosítási szerződési jog egységesítésére irányuló munkafolyamatok később indulnak el. ${ }^{2}$ A közösségi joganyagban megjelenő egyéb jogszabályok szintén hatással vannak a biztosítási szerződési jogra, ezek általában a fogyasztói szerződéseket érintő, másodlagos jogforrásokban megjelenő normák (ezekhez kapcsolódó európai bírósági gyakorlat), ${ }^{3}$ a biztosítók piaci magatartását érintő jogszabály, ${ }^{4}$ a jogérvényesítéssel kapcsolatos, eljárásjog területére eső normák, ${ }^{5}$ de ide sorolható alapvetően a biztosítók üzleti tevékenységét is érintő irányelv, ${ }^{6}$ amely a nők és férfiak közötti megkülönböztetés tilalmát írja elő.

A szolgáltatás szabad áramlásának következményeként a fogyasztók választási lehetősége megnövekedett. Ugyanakkor az Európai Bizottság által a biztosítási szerződések tagállamokon keresztüli kereskedelmét érintő akadályok vizsgálata céljából felállított szakértői csoport átfogó jelentése szerint a szerződési jog különbségei hátráltatják a biztosítási termékek határon átnyúló értékesítését, és több mint 20 évvel az egységes piac létrehozását követően még távolról sem müködik olajozottan a határon átnyúló kereskedelem a biztosítási ágazatban. ${ }^{7}$

Az EU-szabályok a fogyasztó védelme érdekében nagy hangsúlyt helyeznek a biztosítók prudens és szolvens működésének biztosítására, de a szerződéses kapcsolatokban a fogyasztók védelmének fontos eszköze a biztosítási szolgáltatást nyújtók számára előírt tájékoztatási kötelezettség is. A Szolvencia II. irányelv ${ }^{8}$ - amely 13 irányelv felváltását jelenti egyetlen jogszabállyal - szabályozza mind az élet-, mind pedig a nem-életbiztosítási szerződések területén a biztosítót terhelő tájékoztatási kötelezettséget. A biztosítási piac és a szerződéskötési folyamat fontos résztvevői a biztosításközvetítők, akikre vonatkozó közjogi szabályanyag ${ }^{9}$ is egyre szigorúbb elvárásokat tartalmaz.

Az elmúlt évek legfrissebb európai uniós szabályozási fejleményei a lakossági befektetési csomagtermékekkel és biztosítási alapú befektetési termékekkel kapcsolatos tájékoztatás javítása, összehangolása, illetve a fokozottabb befektetővédelem érdekében elfogadott ún. PRIIPs rendelet ${ }^{10}$ és a már hivatkozott IDD irányelv. Mindkettő markáns - az előbbi szerződéskötés előtti tájékoztatási, míg az utóbbi értékesítési és tájékoztatási - szabályokat fogalmaz meg a biztosítási termékek vonatkozásában.

A közjogi szabályok áttekintése kívül esik jelen tanulmány körén, kizárólag a tájékoztatási kötelezettség és a kárfelelősség összefüggéseire térünk ki. 


\section{A szolgáltatást nyújtók tájékoztatási kötelezettsége}

Az említett európai folyamat természetesen tükröződik a magyar jogalkotásban, jogharmonizációs kötelezettségünk okán, de a Ptk. kodifikáció során figyelemmel voltak a biztosítási szerződési jogegységesítési törekvésekre is. Az európai biztosítási szerződések alapelveit rögzítő PEICL 2:201 Cikk is rendelkezik a biztosítót a prekontraktuális szakaszban terhelő tájékoztatási-együttműködési kötelezettségről, előírja, hogy a szerződő számára elegendő időt kell biztosítani annak mérlegelésére, megköti-e a szerződést, avagy sem. ${ }^{11}$

\section{A tájékoztatással kapcsolatos szabályok sajátosságai}

A biztosítási jogviszonyban a tájékoztatási kötelezettség rendkívül összetett, mert figyelemmel kell lenni a Ptk. általános és a biztosítási jogviszonynál megjelenő különös szabályaira, a több szinten megjelenő közjogi normákra, a Bit. szabályaira, illetve a közvetlenül alkalmazandó EU-normákra, a PRIIPs rendeletre, a különös szerződéskötési módszerekre vonatkozó szabályokra, továbbá arra, hogy e jogszabályok alapján fogyasztónak vagy ügyfélnek (lakossági befektetőnek) minősül-e a szerződést kötni kívánó személy. A Bit. alkalmazásában fogyasztó (Bit. 4. \$33.) a fogyasztókkal szembeni tisztességtelen kereskedelmi gyakorlat tilalmáról szóló 2008. évi XLVII. törvényben (Fttv.) meghatározott személy, amely nem teljesen esik egybe a Ptk.-ban meghatározott fogalommal, míg az ügyfél fogalma ennél tágabb kört ölel fel. ${ }^{12}$

Lényeges eltérés a közjogi normáktól, hogy a Ptk. szabályai általában és a biztosítási szerződésre vonatkozó szabályok alapvetően diszpozitívak, kizárólag a fogyasztói biztosítási szerződéseknél tartanak fenn egyoldalúan kógens rendelkezéseket.

A biztosítás mint „jogi termék” értékesítése történhet közvetlenül a biztosító részéről, de jellemzőbb a biztosításközvetítők tevékenységének a beékelődése a biztosító és a potenciális szerződő fél közé. A Bit. - az európai normáknak megfelelően - a biztosítási értékesítés átfogó fogalma alatt a biztosítói értékesítést és a biztosításközvetítői tevékenységet is érti. A jövőben az egyes biztosítási termékek jóváhagyására a biztosítók egy belső eljárási rendet kötelesek kidolgozni és müködtetni, biztosítva a folyamatos felülvizsgálatot, és kötelesek az adott terméket értékesítő biztosításértékesítők rendelkezésére bocsátani az összes információt, amellyel összhangban ajánlhatja a közvetítő a terméket, vagy nyújthat tanácsot (Bit. 131/A).

A közjogi szabályokat vizsgálva, a tájékoztatási kötelezettség körében fontos figyelemmel lenni arra is, hogy biztosítót vagy biztosításközvetítőt (függő vagy független biztosításközvetítőt, a közvetítést fötevékenységként vagy kiegészítő tevékenységként folytató közvetítőt) terhel a tájékoztatási kötelezettség; élet- (azon belül is befektetési) elemeket hordozó vagy sem, vagy nem-életbiztosítási szerződésről van szó; társul-e tanácsadással ${ }^{13}$ vagy sem; sor kerül-e ún. keresztértékesítésre (azaz a biztosítási terméket kiegészítő termékkel vagy szolgáltatással kínálják, vagy fordítva és a biztosítás a kiegészítő termék) vagy sem.

\subsection{A tájékoztatási kötelezettség a prekontraktuális szakaszban}

A biztosítási szerződéskötési folyamatban nagy hangsúly helyeződik a prekontraktuális szakaszra, illetve e szakaszban a felek együttmüködési és tájékoztatási kötelezettségére, amely területen - az előzőekben kifejtettek alapján - erőteljesen jelen van a jogharmonizációs kötelezettség. A Bit. 2017. évi CXLV. törvénnyel megvalósuló módosításával a közjogi szabályozás a már hivatkozott EU-szabályokon alapszik.

A közjogi normákban szabályozott tájékoztatási kötelezettség megsértése közjogi szankciókat vonhat maga után, ${ }^{14}$ de a szerződéses kapcsolatban felmerülhet a magánjogi jogkövetkezmények alkalmazása is, amennyiben annak jogszabályi feltételei fennállnak. A két jogterület elhatárolását jól jelzi például, hogy a Bit. a biztosítót terhelő figyelemfelhívó tájékoztatással kapcsolatban kifejezetten utal arra, annak megsértése a Bit.-ben meghatározott jogkövetkezményeket vonja maga után, és nem érinti az általános szerződési feltételek vagy azok egyes kikötései - a Ptk.-ban meghatározottak szerinti - szerződéses tartalommá válását.

A közjogi normákban szabályozott tájékoztatási kötelezettség megsértése közjogi szankciókat vonhat maga után, de a szerződéses kapcsolatban felmerülhet a magánjogi jogkövetkezmények alkalmazása is.

A tájékoztatási kötelezettség - biztosítóra és biztosításközvetítőre, élet- és nem-életbiztosításra egyaránt vonatkozó - általános szabályait a Bit. határozza meg. A biztosítási alapú befektetési termékekkel kapcsolatos PRIIPs rendelet a szerződéskötés előtti tájékoztatás - formai és tartalmi - követelményeit rögzíti, és előírja, hogy föszabályként a termék előállítója köteles a rendeletnek megfelelő formában, tartalommal elkészíteni és honlapján közzétenni a kiemelt információkra vonatkozóan egységes terméktájékoztatót (ún. Key Information Document/ KID), amely világosan és érthetően foglalja össze a legfontosabb termékjellemzőket. ${ }^{15}$ A PRIIPs rendeletben foglaltak szerint közigazgatási szankció mellett polgári jogi szankció, kártérítési felelősség is kapcsolódik a jogszabálysértéshez.

A Bit. szabályai megkövetelik, hogy a jövőben a nem-életbiztosítási termék kidolgozója is köteles az európai szabálynak ${ }^{16}$ megfelelően termékismertetőt összeállítani, amelyet a termék értékesítése esetén az ügyfélnek át kell adni.

\subsubsection{A függő közvetítők jogi helyzete}

A Bit. kifejezetten rendelkezik a közvetítői tevékenység ellátásával (mulasztással) összefüggésben okozott károkért való felelősségről is, amely kapcsolódhat a tájékoztatási kötelezettség nem vagy nem megfelelő teljesítéséhez.

Az ügynök a biztosítási szerződést a biztosítóval fennálló munkaviszonya keretében vagy a biztosító megbízása alapján közvetíti. Ez utóbbi esetben a jogviszony általában tartós közvetítői 
jogviszonynak minősül, amit a korábbi jogszabályhoz kapcsolódó bírói gyakorlat is megerősít. ${ }^{17}$ Az ügynök a biztosító irányában a közvetítői szerződés teljesítéséért ennek megfelelően vagy a munkajogi szabályok, vagy a polgári jogi szabályok, azon belül is a szerződésszegésért való felelősségi/kárfelelősségi szabályok szerint felel. A Ptk. 6:142. \$-a szerint a szerződésszegési kárfelelősség alóli mentesüléshez azt kell bizonyítania, hogy a szerződésszegést ellenőrzési körén kívül eső, a szerződéskötés időpontjában előre nem látható körülmény okozta, és nem volt elvárható, hogy a körülményt elkerülje, vagy a kárt elhárítsa. Az ügyfél felé az ügynök által a közvetítői tevékenységének ellátásával (mulasztással) összefüggésben okozott kárért minden esetben az a biztosító felelős (a sérelemdíjért is), amely termékének a közvetítése során történt a károkozás [Bit. 385. \$ (2)-(3) bek.]. ${ }^{18}$ Függő közvetítő a vezérügynök is, aki a hatályos szabályok szerint már nemcsak természetes személy, hanem vezérügynöki tevékenységet folytató vállalkozás is lehet, és a biztosítóval létesített jogviszonytól függően alakul a felelőssége az ügynökre vonatkozó szabályoknak megfelelően. Ezeket a szabályokat a kiegészítő biztosításközvetítői tevékenységet végző személyekre is alkalmazni kell, akiknek a tevékenységéért mindig a megbízója - biztosító vagy biztositásközvetítő - felel.

A többes ügynök általában tartós közvetítői jogviszonyt létesít a biztosítóval, amelynek megszegéséért a polgári jog szabályai szerint felel, és ha azzal kapcsolatban a biztosítónak kára is keletkezik, csak a szerződésszegéssel okozott kárfelelősség szigorú szabályai alapján mentesülhet. Az ügyfél felé a közvetítői tevékenység ellátásával (mulasztással) összefüggésben okozott kárért (a sérelemdijért is) ilyen esetben is az a biztosító a felelös, amely termékének közvetítése során történt a károkozás [Bit. 391. $\$(2)-(3)$ bek.].

A biztosító kárfelelössége kiterjed a függő közvetítő által közvetítésre igénybe vett, vele munkaviszonyban, megbízási, illetve munkavégzésre irányuló egyéb jogviszonyban álló személy károkozására is.

A Ptk. 6:62. $\$(1)$ bekezdésében az együttmüködési és tájékoztatási kötelezettség nevesített szerződési jogi alapelvek egyikeként szabályozott. ${ }^{19} \mathrm{~A}$ kárfelelősséggel kapcsolatos Bit. szabályok alapvetően olyan helyzetekben értelmezhetők, ha az ügyfél és a biztosító között nem jön létre szerződés, és ezzel összefüggésben az ügyfélnek kára keletkezik, amelyet a függő közvetítő okoz. A Bit.-ben előirt, a prekontraktuális szakaszban megjelenő tájékoztatási kötelezettség megsértéséhez kapcsolódó magánjogi jogkövetkezmény, a kárfelelősség a Ptk. szerződésen kívüli kárfelelősségi szabályai alapján vizsgálandó. Az elméletben és a gyakorlatban is bizonytalan a Bit. és a Ptk. egymáshoz való viszonya; azaz vitatott, hogy abban az esetben, ha nem állandó jellegű a megbízási jogviszony a biztosító és a közvetítő között, illetve a károsult igényét nem az alkalmazott károkozásáért való felelősségi szabályok szerint érvényesíti, van-e lehetősége a biztosítónak a Ptk. megbízottért való felelősségi szabály alapján mentesülésre vagy sem. Azaz hivatkozhat-e a biztosító arra, hogy őt a megbízott megválasztásában, utasításokkal való ellátásában és felügyeletében felróhatóság nem terheli [Ptk. 6:542. \$ (1) bek.]. Azt az álláspontot tartjuk elfogadhatónak, mely szerint a Bit. szabályai valójában a felelősség alanyát pontosítják, különös elvárhatósági szabályokat fogalmaznak meg, de a polgári jogi kárfelelősség fennállásának feltételeit a Ptk. alapján kell megállapítani. Ez azt jelenti, hogy a biztosító szerződésen kívüli kárfelelősségénél - a biztosító és a biztosításközvetítő közötti jogviszonynak megfelelően - alkalmazásra kerülnek az alkalmazott [Ptk. 6:541 $₫(1)$ bek.], illetve a megbízott (Ptk. 6:542. §) károkozásáért fennálló felelősségi szabályok. ${ }^{20}$

Ehhez azonban egy további kérdés is kapcsolódik: a közvetítői jogviszonyra vonatkozhat-e a megbízott károkozásáról rendelkező szabály. A Ptk. a megbízási típusú szerződések között helyezte el a közvetítői szerződést (mögöttes szabály a megbízás), így arra a következtetésre kell jutnunk, hogy a megbízott károkozásáért való kárfelelősségi szabályokat a közvetítői jogviszonyra is alkalmazni kell, függetlenül attól, hogy számos sajátosságot hordoz a jogviszony. Mint arra már utaltunk, a biztosító és a függő közvetítő között - ha nem munkaviszony áll fenn - jellemzően tartós közvetítői jogviszony jön létre, amely esetben a károsult a biztosítóval szemben akár az alkalmazottért való felelősség szabályai szerint is érvényesítheti az igényét [Ptk. 6:542. \$ (2) bek.]. Az 1959-es Ptk. helyes értelmezésével mondta ki a bíróság, hogy az állandó megbízási jogviszony esetén a megbízottáltal a harmadik személynek okozott kárért a megbízó munkáltató módjára, az alkalmazottért való kártérítés szabályai szerint felel, ezért ilyen esetben a megbízott és a megbízó egyetemleges marasztalása kizárt (BDT2012. 2703).

Ha vitás vagy nem állapítható meg, hogy mely biztosító termékének a közvetítése során okozta a többes ügynök a kárt, a többes ügynök köteles megtéríteni azt.

A felróhatóság értékelésénél az „adott helyzetben általában elvárhatóság” konkretizálódik, hiszen a professzionális kárfelelősségnél a károkozó és a károsult között jellemzően egy aszimmetrikus viszony van, és az általában elvárható magatartást befolyásolják a szakmára irányadó szabályok: a biztosítótól, közvetítőtől elvárható magatartás körében értékelést nyernek a Bit. által szabályozottak. Ily módon összekapcsolódik a közjogi és a magánjogi szabály a kárfelelösségben.

A károsult igényérvényesítését segítheti az a szabály, amely szerint, ha vitás vagy nem állapítható meg, hogy mely biztosító termékének a közvetítése során okozta a többes ügynök a kárt, a többes ügynök köteles megtéríteni azt.

A Ptk. a más személyért fennálló felelősség körében elhagyta az 1959-es Ptk.-ban alkalmazott megoldást, a megtérítési igényről nem rendelkezik, de -álláspontunk szerint - a biztosító a közjogi szabályok alapján sincs elzárva attól, hogy helytállását követően az ügynökkel (vezérügynökkel) szemben munkajogi vagy polgári jogi szerződésszegési kárfelelősség, míg a többes ügynökkel szemben polgári jogi szerződésszegési kárfelelősség alapján érvényesítsen igényt.

\subsubsection{A független biztosításközvetítő jogi helyzete}

A függő-független minősítés alapja, hogy míg a függő közvetítő - az elözőekben kifejtettek szerint - pontosan meghatározható biztosító felelösségvállalása mellett lép piacra, addig a független közvetítő ezt a saját nevében és saját kockázatára teszi. 


\section{a) Az alkusz és az ügyfél szerződéses kapcsolata}

A független biztosításközvetítő, azaz az alkusz az ügyfél megbízásából jár el, így a tevékenységéért (mulasztásáért) a biztosító nem felel, nem tekinthető a biztosító közreműködőjének sem. Lényeges eltérés a függő közvetítői helyzettől, hogy az ügyfél és az alkusz közötti szerződés már a jogviszonyból eredő kötelezettséget ró az alkuszra. Az alkusz előkészíti a biztosítási szerződés megkötését, de tevékenysége kiterjedhet - az ügyfél képviseletében - a szerződés megkötésére, a megbízó igényeinek érvényesítésében történő közreműködésre. Az együttmüködési és tájékoztatási kötelezettség az alkusz részére szerződéses kötelezettséggé válik, a megbízója irányában ennek a kötelezettségnek a megszegése szerződésszegést jelent, és a kárfelelősség is a szerződésszegéssel okozott kárfelelösség szerint alakul. Az alkusz vonatkozásában is különbséget tesz a Bit. tanácsadással és tanácsadás nélküli értékesítés között, de tanácsadás nélküli értékesítés esetén is köteles a biztosítási szerződés megkötésének előkészítése során elegendő számú, a piacon hozzáférhető biztosítási terméket tárgyszerűen elemezni és ezt az elemzést az ügyfél részére igazolható módon átadni. Csak kivételesen tekinthetnek el ettől a kötelezettségtől. ${ }^{21} \mathrm{Az}$ alkusz is felelős azoknak a személyeknek a magatartásáért, akik a nevében járnak el, ami összhangban van a Ptk. 6:148. \$ szakaszában megfogalmazott, közreműködőért való felelősségi szabállyal (mindezek fedezetét jelenti a kötelezően kötendő felelősségbiztosítási szerződés).

A Bit. 402. $\$(1)$ bek. külön kiemeli, hogy az alkusz a tevékenysége során a biztosítási szakmai szabályokat mindenkor megtartva köteles eljárni, az e kötelezettsége elmulasztásáért, így különösen a téves tanácsadásért, téves tájékoztatásért, a szabálytalan díjkezelésért, a nyilatkozatok hibás vagy késedelmes továbbításáért felelős. Ennek megsértése közjogi felelösséget von maga után, amit jól tükröz a Kúria döntése, ugyanis az alkusszal szemben indult fogyasztóvédelmi célvizsgálat során hozott határozat elleni felülvizsgálati eljárásban megállapította az ajánlat késedelmes továbbítása miatt az alkusz közjogi felelősségét, és fogyasztóvédelmi bírságot szabott ki (BH2017. 387.). Emellett felmerülhet a magánjogi jogviszonyban a szerződésszegéssel okozott kárfelelősség.

$\mathrm{Az}$ alkusz jellemzően a biztosító által elkészített nyomtatványt, dokumentumot használja a közvetítés során, amelynek hibájáért nem felel. A Bit. 402. $\$(3)$ bek.-ben meghatározott különös mentesülési szabály alapján ugyanis az alkusz minden biztosítási termék közvetítésénél mentesül a felelősség alól, ha bizonyítja, hogy a biztosító által rendszeresített, a szerződéskötés során alkalmazott nyomtatvány vagy dokumentum hibája miatt következett be a téves tájékoztatás vagy hibás nyilatkozat megtétele.

E jogszabályi rendelkezés értelmezésével arra a következtetésre juthatunk, hogy az alkusz számára e körülmények fennállása - a jogirodalmi állásponttal egyetértve - nemcsak a közjogi szankció alkalmazása alól eredményezhet mentesülést, hanem a magánjogi - akár szerződésen kívüli, akár szerződésszegési - kárfelelősség körében különös mentesülési okként értékelendő. ${ }^{22} \mathrm{E}$ rendelkezések alapján is megfigyelhető a közjogi és a magánjogi szabályok összekapcsolódása a kárfelelősségben.
A biztosításközvetítő hivatkozott körülmények alapján történő mentesülése esetén elötérbe kerül a károsult ügyféllel szemben a biztosító (termék előállítója) - deliktuális vagy kontraktuális - kárfelelőssége. A PRIIPs szerint (11. §) a biztosítási alapú befektetési termék elöállítója pusztán a kiemelt információkat tartalmazó dokumentum alapján nem tartozik polgári jogi felelösséggel, és meghatározza, a tájékoztató mely hibája von maga után felelösséget: ha a tájékoztatót nem a rendeletnek megfelelö formában, tartalommal készítette el, az megtévesztő, nem pontos, vagy nem áll összhangban a kötelező erejü, szerződéskötést megelőző és szerződéses dokumentumok vonatkozó részeivel. A felelősség kizárólag a szerződő felé áll fenn, míg az esetleges kedvezményezett ezekre a körülményekre hivatkozással kárigényt nem támaszthat. Lényeges arra is utalni, a rendelet szerinti felelősség - eltérően a magyar szabályoktól - nem zárható ki és nem is korlátozható, de egyébként a rendeletben nem szabályozott polgári jogi felelősségi kérdések tekintetében az alkalmazandó nemzeti jog az irányadó.

\section{b) Az alkusz és a biztosító kapcsolata}

Az alkusz a biztosító hozzájárulása esetén, amelyet általában az alkusz és a biztosító közötti megállapodás rögzít, de mindenképpen az ügyfél megbízása, illetve felhatalmazása alapján válhat jogosulttá - többek között - a szerződésből eredő jogok és kötelezettségek teljesítésében és lebonyolításában való közremüködésre [Bit. 398. \$ (2) bek.].

\section{Vitatható az a bírósági gyakorlat, amely a biztosító} képviseletében eljáró személynek tekinti az alkuszt.

„A biztositók a hozzájárulásukat a piaci gyakorlat szerint - a hivatkozott rendelkezésnek megfelelöen - a biztositók és az alkuszok között megkötött elözetes és általános alkuszi megállapodásokban szokták megadni, amelyekben rögzítik továbbá az együttmüködésük rendjét is. Az ilyen megállapodás azonban nem terjedhet túl az együttmüködés technikai kereteinek meghatározásán, és nem foglalhat magában a biztositótól eredö, az alkusznak címzett megbizást. Az alkusz nem sérti meg a Bit. rendelkezéseit azzal, ha szerzödéses kapcsolatban áll több biztosítóval, ám a szerzödések tárgya semmiképp sem lehet biztosításközvetítésre irányuló megbízás. ${ }^{23}$ A hivatkozott - és az MNB állásfoglalással is megfelelően értelmezett - jogszabály alapján nem a biztosító, hanem az ügyfél - mint szerződő fél - felhatalmazása szükséges ahhoz, hogy a szerződésből eredő jogok teljesítésében, lebonyolításában az alkusz közreműködjön. A biztosító mindehhez „csak” hozzájárulhat. Éppen ezért vitatható az a bírósági gyakorlat, amely - az alkusz és a biztosító közötti együttműködési megállapodásra tekintettel - a biztosító képviseletében eljáró személynek tekinti az alkuszt, és az alkusztól elvárt együttműködési kötelezettség megsértéséért (nem tájékoztatta az ügyfelet a biztosítási szerződéssel kapcsolatos alaki követelményekről) a biztosítót kárfelelősséggel terheli (BH2002. 266.). 


\subsection{A tájékoztatási kötelezettség online értékesítés során}

A Ptk. rendezi azt a kérdést, hogy az elektronikus úton tett jognyilatkozat mikor elégíti ki az írásbeliség követelményét [Ptk. 6:7. \$ (3) bek.], rendelkezik az elektronikus utat biztosító félnek a körben megjelenő tájékoztatási kötelezettségéről, az adatbeviteli hibák javításáról, továbbá az elektronikus szerződési jognyilatkozat hatályossá válásáról, a jognyilatkozat visszaigazolásáról és az ajánlati kötöttség megszűnésének speciális esetéről. Ezek a szabályok fogyasztó és vállalkozás közötti szerződésben kógensek (6:82.\$-6:85. \$). ${ }^{24}$ Fontos kiemelni, hogy a Bit. szerint a biztosító elfogadó nyilatkozatát fokozott biztonságú elektronikus aláirást tartalmazó dokumentum igazolhatja, amely esetben a Bit. szerinti tájékoztatót is köteles az ügyfél számára folyamatosan és könnyen elérhető módon elektronikus úton hozzáférhetővé tenni. Amennyiben szervezett távértékesítés formájában történik a biztositási termék közvetítése, értékesítése - a Bit és a PRIIPs szabályai mellett -, figyelemmel kell lenni a 2005. évi XXV. törvényre, kötelezően kifejezetten csak fogyasztóval szemben érvényesülő szabályaira is. E jogszabály a tájékoztatási kötelezettség elmulasztásának sajátos - magánjogi - jogkövetkezményét rendeli alkalmazni, mégpedig oly módon, hogy a biztosítót (biztosításközvetítőt) e jogszabály alapján a prekontraktuális szakaszban terhelö tájékoztatási kötelezettség megsértésének sajátos jogkövetkezményét a létrejött biztosítási jogviszonyban „vonja le”, lehetőséget adva a fogyasztónak arra, hogy a jogszabályban meghatározott feltételek megléte esetén éljen az elállás, illetve felmondás jogával (Tv. 6. §). E jog gyakorlására vonatkozó határidő attól függ, hogy a tájékoztatás mely tartalmi elemével kapcsolatban áll fenn a tájékoztatási kötelezettség megsértése. A Bit. kifejezetten utal a telefonon történő értékesítés esetén a vonatkozó külön jogszabályok tájékoztatással kapcsolatos rendelkezéseinek a betartására, megkövetelve, hogy ilyen esetben a biztosítási szerződés megkötése után a Bit. szerinti tájékoztatást haladéktalanul meg kell adni az ügyfél által választott módon [Bit. 152. \$ (3) bek.].

A MABISZ 2017. novemberi konferenciáján elhangzottak szerint minden hatodik nem-életbiztosítási szerződés online értékesítő által köttetett. ${ }^{25} \mathrm{Az}$ online értékesítést segíti a biztosítási termékek bemutatását, összehasonlítását szolgáló és a biztosításközvetítés során használt elektronikus felületekről szóló MNB 5/2015. (V.05.) ajánlás. Ebben megfogalmazódik az elektronikus felület minimális tartalmával, funkciójával és az ügyfelek tájékoztatásával szembeni elvárások meghatározása, iránymutatás az e-ügyfél biztosítási igényeinek és szükségleteinek felmérésére, a felületek átláthatóságának elősegítése stb. Fontos említést tenni az MNB újabb ajánlásáról [MNB 2/2017. (I.12.)], amellyel a közösségi és publikus felhőszolgáltatások igénybevételéről ad gyakorlati útmutatást, ezzel segítve az egységes jogalkalmazást.

\subsection{Tájékoztatási kötelezettség a biztosítási szerződéses jogviszonyban}

A fennáló biztosítási szerződési jogviszonyban a tájékoztatási kötelezettség alapvetően a biztosítónál jelentkezik, de az is előfordul, hogy a már megkötött biztosítási szerződésnél a tájékoztatási kötelezettséggel járó jogi helyzetekben - módosításánál, megújításánál, a szerződés- kötés után az ügyfél részéről teljesített fizetésnél (kivéve a folyamatos dijfizetést és az ütemezett fizetéseket) - függő biztosításközvetítő működik közre. A fennálló biztosítási jogviszonyban mind a biztosítónak, mint a közvetítőnek figyelemmel kell lenni egyrészt a közjogi normákban meghatározottakra, másrészt a Ptk. együttműködési és tájékoztatási kötelezettségre irányadó szabályaira. Ilyen jogi helyzetben a biztosító felel a szerződésszegéséért, illetve szerződésszegéssel történő károkozásáért a Ptk. 6:148. \$-a - azaz a közremüködőért való felelősség - alapján.

Az ügyfél is kialakíthat az alkusszal tartós jogviszonyt, amelyben az alkusz közreműködhet a biztosítási szerződés módosításában, megújításában, amikor a tájékoztatási kötelezettség a Bit. szabályai szerint alakul, annak megszegése az alkusz részéről szerződésszegésnek minősül, és szerződésszegéssel okozott kárfelelősséget is maga után vonhat.

\section{Összegzés}

Jelen tanulmányban igyekeztünk rámutatni a biztosítási szerződések értékesítéséhez kapcsolódó és a Ptk. új szabályaival, valamint a közjogi szabályokkal összefüggésben jelentkező kárfelelősségi helyzetekre, amelyek a biztosítási piac résztvevői számára komoly kockázati tényezőként vannak jelen. Mindemellett a jogalkalmazás számára is nagy kihívást jelenthet egy konkrét jogvita során a jogszabályok egységes értelmezése és alkalmazása, ami érdeke a biztosítóknak, biztosításközvetítőknek, de legfőképpen érdeke a károsult ügyfeleknek.

\section{HIVATKOZÁSOK}

"Háromgenerációs" irányelvet: Sir Leon Brittan, a Bizottsàg akkori pénzügyi szolgáltatásokért felelős tagja nevezte el háromgenerációs irányelveknek, utalva a harmonizáció lassú ütemére. Nicholas Paul - Richard Groly (1991): EC Insurance Law. European Practice Library. Cameron Markby Hewitt, p. 11.

Lásd: Ujváriné Antal Edit: Az egységes belső biztosítási piacra vonatkozó közösségi jog átvételének szervezeti és anyagi jogi kérdései. In Fazekas Judit - Asztalos Zsoofia - Sós Gabriella (szerk.) (2003): Csatlakozás-Jogközelítés. Az acquis communautaire adaptalasa a magyar jog- és intézményrendszerbe. KJK KERSZOV Budapest, VIII. fejezet pp. 227-285., valamint A biztosítási szerződési jog változásai az európai jogfejlődés áramában. Európai Tükör, XV évfolyam 10. szám, pp. 37-52.

" „Restatement of European Insurance Contract Law" Project Group 1999-szeptemberében kezdte meg munkáját, majd szerződési jog felé szabályrendszer. Biztosítási Szemle, 2007 február. A Project Group 2009-ben hozto nyilvánossá́gra azáltala kidolgozott principles of Furopean Insurance Contract Law (PEICL)" azazaz európai biztositási szerzö́dések alapelveit. A 2011/2013/(INI) EP állásfoglalás alapián döntés született a szakértöic csoport létrehozásáról (2013/C 16/03). "Így a 93/13/EGK irányelv a fogyasztóval kötött szerző̉dések tisztességtelen feltételeiről, a fogyasztói pénzügyi szolgáltatások távértékesitési rendszerben történó értékesítésére vonatkozó 2002/65/EK irányelv. Bár nem tárgya jelen tanulmánynak az ezzel kapcsolatos bírósági gyakorlat elemzése, de érdemes utalni a C 96/14. sz. ügyben hozott itéletetre (Jean Claude Van Hove kontra CNP Assurances SA), annak jelentősége folytán. Az itélet indoklása szerint a biztositási szerzödés elsődleges tárgyának meghatározására irányuló feltételek akkor tekinthetők világosnak és érthetỏen megfogalmazottnak, ha nemcsak nyelvtanilag érthetők a fogyasztó számára, hanem átláthatóan feltüntetik a biztosítási mechanizmus konkrét múködését is, figyelembe véve az e feltételeket tartalmazó szerzódésegyüttest, oly módon, hogy a fogyasztó pontos és érthetó szempontok alapján értekelhesse a számára ebból eredo gazdasági kôvetkezményeket. Az a tény, hogy a biztositási szerzódés egyidejuleg kotott kôlcsonnzzerzodesekhez kapcsolodik, szerepel jatszhat a szerződési feltetelek átláthatóságára vonatkozó követelmény tiszteletben tartásának vizsgálatában. 
${ }^{4} \mathrm{~A}$ Bizottság 267/2010/EU rendelete a biztositási ágazatbeli megállapodások, döntések és összehangolt magatartások egyes csoportjaira történő alkalmazásáról, továbbá az üzleti vállalkozások fogyasztókkal szemben folytatott tisztességtelen kereskedelmi gyakorlatarrol szolo 2005/29/EK irányel

44/2001/EK rendelet (Brüsszel I.) a joghatóságról, valamint a határozatok elismerésérỏl és végrehajtásáról a polgári és kereskedelmi ügyekben; az 593/2008/EK rendelet (,.Róma I.”) a szerződéses kötelmekre alkalmazandó jogról; a

${ }^{6} 2004 / 113 /$ EK irányelv (Gender direktíva)

82009/138/EK ín (letöltve: 2018.03.13.)

XXXVUU törvény bemut II.). Lásd dr. Szedlák Katalin Viktória: A biztositási tevékenységrőll szóló 2014. évi . EU (IDD) irányelv

$1286 / 2014 / \mathrm{EU}$ (PRIIPs) rendelet,

"https://www.uibk.ac.at/zivilrecht/forschung/evip/restatement/sprachfassungen/peicl-hun.pdf (letöltve: 2018.03.02.) ${ }^{12}$ Fttv. $2 . \$$ „a) fogyasztó: az önálló foglalkozásán és gazdasági tevékenységén kívül eső célok érdekében eljáró természetes személy"

Ptk. 8:1. § „3. fogyasztó: a szakmája, önálló foglalkozása vagy üzleti tevékenysége körén kívül eljáró természetes személy":

Bit. 4. \$ „101. ügyfél: a szerződő, a biztosított, a kedvezményezett, a károsult, a biztositó számára szerződéses ajánlatot tett és a biztositó szolgáltatására jogosult más személy, továbbá a független biztositásközvetítő esetében az a személy is, aki a független biztositásközvetítővel alkuszi megbízási szerződést kötött

${ }^{13} \mathrm{~A}$ Bit. túlmegy az EU minimum szabályokon azzal, hogy befektetési termékek esetében elöírja a kötelező tanácsadást.

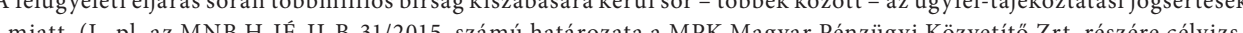
gálat lezárásáról: MNB H-JÉ-II-B-51/2016. számú határozata a Consut Pénzügi Tańcsodó és Biztositásközvetitő

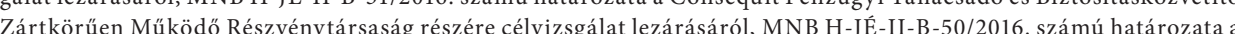
Consequit Alkusz Kft részére célvizgó́lat leźn Biztositás és Kockázat, III. évfolyam 2. szám pp. 80-88.

${ }^{15}$ Lásd a jogszabályok egymáshoz való kapcsolatáról Lencsés Katalin - Paál Zoltán: Több vagy jobb minőségủ tájékoztatás a befektetési termékek piacán? Az Európai PRIIPS szabályozás státusza és kihívásai. Biztosítás és Kockázat, II. évfolyam 3. szám, pp. 12-29.; továbbá Lencsés Katalin: Bevezetés az új európai biztositási értékesitési (IDD) irányelvbe. Biztositás és Kockázat, III. évfolyam 2. szám, pp. 16-31.

${ }^{16} 2017 / 1469$ bizottsági (EU) végrehajtási rendelet a biztosítási termékismertető egységesített mintadokumentumának meghatározásáról

${ }^{17}$ BDT2003. 856., BDT2006. 1397

${ }^{18}$ Kúria Pfv. 21.393/2016/5. határozata

aasd Juhasz Agnes: Az egyuttműködési és tájékoztatási kötelezettséghez kapcsolódó egyes kérdésekről. In Hallok Tamás (felelós szerk.) (2017): SECTIO JURIDICA ET POLITICA, TOMUS XXXV. PUBLICATIONES UNIVERSITATIS MISKOLCINENSIS, Miskolc University Press, pp. 286.

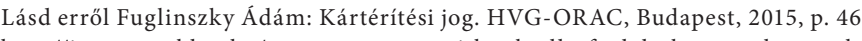

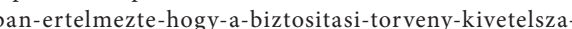

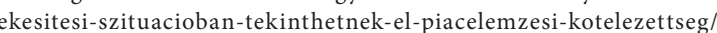

${ }^{22}$ Ezen az állásponton van Fuglinszky, i.m. p. 464.

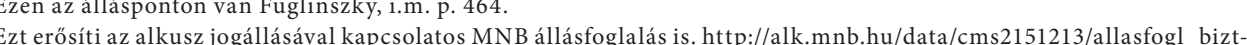
kozv_100423_1.pdf; (letöltve: 2018.03.13.)

http://alk.mnb.hu/data/cms2453567/tmpF4EE.tmp(14406028).pdf (letöltve: 2018.03.13.)

${ }^{24}$ Lásd Dr. Szikora Péter Pál: Az elektronikus közvetítés szabályozására kiadott MNB-ajánlás háttere és hatása. Biztosítás és Kockázat, III. évfolyam 3. szám, pp. 58-78.

${ }^{25} \mathrm{Az}$ új technológiai kihívásokkal foglalkozó a MABISZ konferencia közzétett anyagában szereplő adat.

http://mabiszkonferencia.hu/downloads/2017/Piaci-\%C3\%A9s-szab\%C3\%Allyoz\%C3\%B3i-trendek.pdf (letölttve: 2018.03.13.)

\section{IRODALOMJEGYZEKK}

Fuglinszky Ádám: Kártéritési jog. HVG-ORAC, Budapest, 2015, p. 461., 464.

Helmuth Heiss: Európai Biztositási szerződési jog felé szabályrendszer. Biztositási Szemle, 2007, február

Juhász Âgnes: Az együttmüködési és tájékoztatási kötelezettséghez kapcsolódó egyes kérdésekrổ. In Hallok Tamás (felelőss SZCH.) (2017): SECTIOJURIDICA ET FOLITICA, TOMUS XXXV. PUBLICATIONES UNIVERSITATIS MISKOLCINENSIS, Miskolc University Press, pp. 285-301.

Lencsés Katalin - Paál Zoltán: Több vagy jobb minőségú tájékoztatás a befektetési termékek piacán? Az Európai PRIIPS szabályozás státusza és kihívásai. Biztositás és Kockázat, II. évfolyam 3. szám, pp. 12-29.

https://doi.org/10.18530/6h.2015.3.12

Lencsés Katalin: Bevezetés az ú európai biztositási értékesítési (IDD) irányelvbe. Biztositás és Kockázat, III. évfolyam 2. szám, pp. $16-31$.

https://doi.org/10.18530/bk.2016.2.16

EC Insurance Law. European Practice Library. Cameron Markby Hewitt, p. 11

dr. Szedlák Katalin Viktória: A biztositási tevékenységrỏl szóló 2014. évi LXXXVIIII. törvény bemutatása a Szolvencia II. tükrében Biztosítás és Kockázat, IL évfolyam 1. szám, pp. 12-19.

Dr. Szikora Péter Pál: Az elektronikus közvetités szabályozására kiadott MNB-ajánlás háttere és hatása. Biztositás és Kockázat. III. évfolyam 3. szám, pp. 58-78.

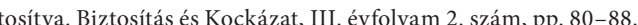
https://doi.org/10.18530/bk.2016.2.80

Ujváriné Antal Edit: Az egységes belső biztositási piacra vonatkozó közösségi jog átvételének szervezeti és anyagi jogi kérdései. In Fazekas Judit - Asztalos Zsófia - Sós Gabriella (szerk.) (2003): Csatlakozás-Jogközelítés. Az acquis communautaire adaptálása a magyar jog-és intęzmenyrendszerbe. KJK KERSZOV Budapest, VIII. fejezet, pp. 227-285.

Ujváriné Antal Edit: A biztositási szerződési jog változásai az európai jogfejlődés áramában. Európai Tükör, XV. évfolyam 10. szám, pp. 37-52.

http://ec.europa.eu//ustice/conract/insurance/index_en.htm (letöltve: 2018.01.12.)

https://www.uibk.ac.at/zivilrecht/forschung/evip/restatement/sprachfassungen/peicl-hun.pdf (letöltve: 2018.03.02.)

http://insuranceblog.hu/a-magyar-nemzeti-bank-allasfoglalasban-ertelmezte-hogy-a-biztositasi-torveny-kivetelszabalya-alapjan-a-biztositasi-alkuszok-milyen-ertekesitesi-szituacioban-tekinthetnek-el-piacelemzesi-http://alk.mnb.hu/data/cms2151213/allasfogl_bizkozv_100423_1.pdf (letôltve: 2018.03.13

http://mabiszkonferencia hu/downloads/2017/Piaci-\%C3\%A9s-szab\%C3\%Allyoz\%C3\%B3i-trendek pdf (letöltve: 2018. 03.13) 